\author{
PATRYCJA EWA HEROD* \\ Wydział Nauk Historycznych \\ Uniwersytet Kardynała Stefana Wyszyńskiego, Warszawa \\ ORCID: 0000-2986-5764
}

\begin{abstract}
Quapropter vobis capitaneo et terrestri notario, nostris Visnensibus, pro nunc et in futurum existentibus et pro tempore constitutis eorumque loca tenentibus ac vicesgerentibus iniungimus et stricte praecipientes mandamus, quatinus secundum exigentiam et continentiam iurium seu privilegiorum regalium nobilitatem eandem terrae Visnensis regant et foveant nullasque invasiones et violentias ipsis et ipsorum cuilibet praesumant exercere, sed cum eis iusto et debito ordine iuris secundum terrae illius consuetudinem antiquam procedant et eos conservare studeant procurentque.
\end{abstract}

Fragment przywileju zatwierdzającego prawa szlachty wiskiej z 7 kwietnia 1519 r. ${ }^{1}$

\title{
SPÓR O REGALE BARTNE W ZIEMI WISKIEJ W LATACH 1502-1519
}

\section{Ziemia wiska od drugiej połowy XIV do XVI w.}

Ziemia wiska znajdowała się na północno-wschodnich krańcach Księstwa Mazowieckiego i graniczyła z ziemią łomżyńską, która wykształciła się w XV w. z obszaru kasztelanii nowogrodzkiej z Łomżą i Ostrołęką ${ }^{2}$. Miastem stołecznym ziemi wiskiej była położona nad Narwią Wizna i to od niej rzeczona jednostka terytorialna otrzymała swoją nazwę. Wizna odgrywała istotną rolę strategiczną, ponieważ strzegła przeprawy przez Narew, która wpadała do Bugu łączącego się z Wisłą. Około połowy XIV w. na Mazowszu wprowadzono nowy podział administracyjno-sądowy (tzw. ziemski), który zastąpił podział na obwody grodowe (kasztelanie) 3. Nowo powstała struktura składała się z okręgów administracyjnych, a zarazem sądowych, określanych w źródłach terminem districtus lub terra, zaś najmniejszą

\footnotetext{
* Dr Patrycja Ewa Herod - adiunkt w Katedrze Historii Nowożytnej w Instytucie Historii WNH UKSW oraz prawnik wykonujący zawód adwokata w Warszawskiej Izbie Adwokackiej. Głównym przedmiotem jej zainteresowań badawczych jest historia prawa oraz ziemi mazowieckiej w średniowieczu i epoce nowożytnej. E-mail:patrycjaewaherod@o2.pl.

1 Iura Masoviae Terrestria: pomniki dawnego prawa mazowieckiego ziemskiego (dalej: IMT), wyd. J. Sawicki, t. 2: 1471-1526, Warszawa 1973, nr 215.

2 H. Samsonowicz, A. Supruniuk, Dzieje polityczne (polowa XIV - poczatek XVI w.), w: Dzieje Mazowsza, t. 1, red. H. Samsonowicz, Pułtusk 2006, s. 320.

3 W dyplomie z 21 X 1349 r., wystawionym przez księcia Bolesława III, użyto jeszcze terminu „kasztelania wyszogrodzka". IMT, t. 1, nr 9; por. Kodeks dyplomatyczny Księstwa Mazowieckiego, obejmujący bulle papieżów,
} 
jednostką administracyjno-sądową stał się powiat. Od wprowadzenia powyższej reformy ziemia wiska składała się z powiatów wiskiego oraz wąsoskiego i taki status quo utrzymywał się do I548 r., kiedy wydzielono z tejże ziemi powiat radziejowski ${ }^{4}$.

Zgodnie z wolą Siemowita III ${ }^{5}$, której dał wyraz w dokumencie z 23 września I379 r. ${ }^{6}$ określającym warunki i zasady sukcesji Mazowsza przez synów z pierwszego małżeństwa7, po jego śmierci ziemia wiska wraz z powiatem goniądzkim miała się znaleźć obok ziem: gostynińskiej, płockiej, płońskiej, rawskiej oraz sochaczewskiej w granicach Mazowsza Zachodniego, zaś powyższe terytorium miał objąć we władanie Siemowit IV ${ }^{8}$. Niniejsze postanowienie weszło w życie I6 czerwca I38I r. wraz ze śmiercią księcia seniora i zapoczątkowało trwały podział ziem mazowieckich na Mazowsze Zachodnie oraz Mazowsze Wschodnie, które znalazło się pod panowaniem Janusza I Starszego 9 .

Siemowit IV, który nagminnie borykał się z problemami finansowymi, już 30 grudnia I40I r. zastawił ziemię wiską wraz z powiatem goniądzkim u swojego brata Janusza I za 4595 kop groszy praskich na dziewięć lat ${ }^{10}$. Jednakże ziemia wiska powróciła do domeny zachodnich Piastów Mazowieckich dopiero w pierwszej połowie I435 r., kiedy została wykupiona w dwóch ratach, tj. I8 lutego ${ }^{\mathrm{II}}$ oraz $\mathrm{I}_{5} \mathrm{marca}^{\mathrm{I2}}$, przez księcia Władysława $\mathrm{I}^{\mathrm{I3}}$.

przywileje królów polskich i książą mazowieckich, tudzież nadania tak korporacyj jako i osób prywatnych (dalej: KDKM), red. J. Lubomirski, Warszawa 1863, nr 70.

4 Atlas historyczny Polski. Mazowsze w drugiej połowie XVI wieku, cz. 2, red. W. Pałucki, Warszawa 1973 , s. 46.

5 Siemowit III (1316/25-1381), syn Trojdena I, brat Bolesława Jerzego II oraz Kazimierza I. Od 1341 r. rządził razem z bratem Kazimierzem I w Czersku i Warszawie, od 1342 r. w ziemi rawskiej, od ok. 1349 r., w wyniku podziału schedy ojcowskiej, książę czerski, liwski i rawski, od 1351 r. w Gostyninie, od 1352 r. lennik króla polskiego, od 1352 r. zastawny książę płocki, od 1355 r. w Sochaczewie i Warszawie, od 1370 r. władca suwerenny, także w Płocku, od 1370 r. w Wiźnie i Zakroczymiu. O. Balzer, Genealogia Piastów, Kraków 1895, s. 457-458; J. Grabowski, Dynastia Piastów Mazowieckich. Studia nad dziejami politycznymi Mazowsza, intytulacją i genealogia książat, Kraków 2012, s. 288-297 i 443-444; K. Jasiński, Rodowód Piastów mazowieckich, Poznań-Wrocław 1998, s. 61-68; zob. tenże, Siemowit III (ok. 1320-1381), w: Polski Słownik Biograficzny (dalej: PSB), t. 37, Warszawa-Kraków 1996-1997, s. 73-75.

6 Data dzienna wystawienia dokumentu podana zarówno w Iura Masoviae Terrestria, jak i w Nowym Kodeksie Dyplomatycznym, tj. 25 II, jest błędna. Niniejszy dokument został wystawiony 23 IX 1379 r.; zob. argumentację: J. Grabowski, Kancelarie i dokumenty książat mazowieckich, Warszawa 1999, s. 46; por. S. M. Szacherska, Zbiór dokumentów i listów miasta Plocka, t. 1, Warszawa 1975, nr 45, s. 71.

7 IMT, t. 1, nr 23; Nowy kodeks dyplomatyczny Mazowsza (dalej: NKDM), cz. 3: Dokumenty z lat 1356-1381, red. J. Sułkowska-Kuraś, S. Kuraś, Wrocław 2000, nr 216.

8 Siemowit IV (ok. 1353/56-1425/26), syn Siemowita III, brat Janusza I Starszego oraz Henryka. Od 1381 r., w wyniku podziału, książę w Gostyninie, Płocku, Płońsku, Rawie, Sochaczewie i Wiźnie, od 1388 r. w Bełzie. O. Balzer, Genealogia, op. cit., s. 473-475; J. Grabowski, Dynastia, op. cit., s. 298-318 i 450-451; K. Jasiński, Rodowód Piastów mazowieckich, op. cit., s. 87-91; zob. A. Supruniuk, Siemowit IV (ok. 1352-1426), w: PSB, t. 37, Warszawa-Kraków 1996-1997, s. 76-81.

9 Janusz I Starszy (ok. 1346-1429), syn Siemowita III, brat Siemowita IV oraz Henryka. Od 1381 r., na skutek podziału, książę w Ciechanowie, Czersku, Liwie, Łomży, Nurze, Warszawie, Wyszogrodzie i Zakroczymiu, od 1391 r. na Podlasiu. O. Balzer, Genealogia, op. cit., s. 465-467; J. Grabowski, Dynastia, op. cit., s. $345-354$ i $444-$ 450; K. Jasiński, Rodowód Piastów mazowieckich, op. cit., s. 78-83; zob. B. Sobol, Janusz I Starszy (ok. 13291429), w: PSB, t. 10, Wrocław-Warszawa-Kraków 1962-1964, s. 581-582.

10 IMT, t. 1, nr 56. Wcześniej Wizna wraz z ziemią wiską znajdowała się w zastawie krzyżackim od 2 XII 1382 r. Siemowit IV wykupił rzeczone terytorium w XII 1401 r. IMT, t. 1, nr 26, 57.

11 Tamże, t. 1, nr 81.

12 Tamże, nr 82.

13 Władysław I Płocki (1406/09-1455), syn Siemowita IV, brat Trojdena II, Siemowita V, Kazimierza II oraz Aleksandra. W latach 1426-34 rządził razem z braćmi w Bełzie, Gostyninie, Płocku, Płońsku, Rawie i Sochaczewie, w latach 1434-42, w wyniku podziału, w ziemi płockiej, płońskiej i Zawkrzu, od 1435 r. w ziemi wiskiej, nad 
Na początku I462 r. Mazowsze znalazło się w bardzo trudnym położeniu, albowiem niespodziewanie stanęło w obliczu wygaśnięcia zachodniej linii Piastów Mazowieckich I stycznia zmarł Siemowit VI ${ }^{14}$, zaś 27 lutego podążył za nim jego młodszy brat, Władysław II ${ }^{15}$. Wówczas rozpoczął się proces inkorporacji Księstwa Mazowieckiego do Królestwa Polski. Ziemia bełska została wcielona przez Kazimierza IV Jagiellończyka 20 kwietnia I462 r. ${ }^{16}$, zaś ziemie gostynińska oraz rawska zostały przysądzone królowi i Koronie I5 listopada 1462 r. na mocy wyroku zwyczajnego sądu królewskiego ${ }^{17}$, co następnie znalazło odbicie w królewskich aktach inkorporacyjnych wydanych jeszcze w tym samym roku, odpowiednio 7 oraz 17 grudnia $^{18}$.

Natomiast 22 października I468 r. wydano wyrok, na mocy którego odsądzono księcia Konrada III $^{19}$ od posiadania ziem płockiej i zawkrzeńskiej oraz przysądzono te ziemie Królestwu Polski i królowi Kazimierzowi IV Jagiellończykowi ${ }^{20}$. Tego samego dnia wydano tożsame wyroki odnośnie do ziem płońskiej i wiskiej ${ }^{21}$, a także ziemi sochaczewskiej i Wiskitek ${ }^{22}$. Jednakże Wizna, tak samo jak ziemie płocka i zawkrzeńska, opowiedziała się za samodzielnością Mazowsza płockiego pod egidą rodzimej dynastii, a mianowicie wschodniej linii Piastów Mazowieckich, zaś Kazimierz IV Jagiellończyk nie był w stanie przełamać oporu miejscowej szlachty i płockiego duchowieństwa, w konsekwencji czego ziemia wiska pozostawała w faktycznym władztwie książąt mazowieckich.

całością ojcowizny (bez Gostynina) od 1442 r. O. Balzer, Genealogia, op. cit., s. 507-508; J. Grabowski, Dynastia, op. cit., s. 331-336 i 467-470; K. Jasiński, Rodowód Piastów mazowieckich, op. cit., s. 133-136. Na temat panowania Władysława I w ziemi wiskiej zob. C. Brodzicki, Poczatki osadnictwa Wizny i ziemi wiskiej na tle wydarzeń historycznych $w$ tym regionie Polski (do 1529 roku), Warszawa 2000; tenże, Ziemia wiska pod rządami księcia Władysława I (1435-1455), „Notatki Płockie”, 164/1995, nr 4, s. 10-15.

14 Siemowit VI (1446-1462), syn Władysława I, brat Władysława II. Od 1455 r. rządził razem z bratem w Bełzie, Płocku, Płońsku, Rawie, Wiźnie i Zawkrzu (do 1459 r. regencja), od 1459 r. w ziemi gostynińskiej. O. Balzer, Genealogia, op. cit., s. 515-517; J. Grabowski, Dynastia, op. cit., s. 340-341; K. Jasiński, Rodowód Piastów mazowieckich, op. cit., s. 150-152; zob. K. Pacuski, A. Swieżawski, Siemowit VI (ok. 1446-1462), w: PSB, t. 37, Warszawa-Kraków 1996-1997, s. 84-85.

15 Władysław II (1447-1462), syn Władysława I, brat Siemowita VI. Od 1455 r. rządził razem z bratem w Bełzie, Płocku, Płońsku, Rawie, Wiźnie i Zawkrzu (do 1459 r. regencja, do 1461 r. w jego imieniu brat), od 1459 r. w ziemi gostynińskiej. O. Balzer, Genealogia, op. cit., s. 517-518; J. Grabowski, Dynastia, op. cit., s. 341-342; K. Jasiński, Rodowód Piastów mazowieckich, op. cit., s. 152-154.

16 IMT, t. 1, nr 107.

17 Tamże, nr 108.

18 Tamże, nr 110 i 112; zob. akty przyłączenia do Korony Rawy i Gostynina IMT, t. 1, nr 111 i 113.

19 Konrad III Rudy (1447/48-1503), syn Bolesława IV, brat Kazimierza III, Janusza II oraz Bolesława V. Rządził razem z braćmi w latach 1454-71 w ziemiach płockiej, płońskiej, wiskiej i zawkrzeńskiej, przy czym do r. 1462 w imieniu książąt regencję sprawowali ich matka Barbara Olelkówna i biskup płocki Paweł Giżycki. Od 1471 r., na skutek podziału, książę czerski i liwski, w latach 1474-89 i potem od 1495 r. wyszogrodzki, od r. 1484 zakroczymski, od 1488 r. nurski, od 1489 r. warszawski. O. Balzer, Genealogia, op. cit., s. 524-526; J. Grabowski, Dynastia, op. cit., s. 366-370 i 479-487; K. Jasiński, Rodowód Piastów mazowieckich, op. cit., s. 167-174; zob. B. Sobol, Konrad Rudy III (ok. 1448-1503), w: PSB, t. 13, Wrocław-Warszawa-Kraków 1967-1968, s. 595-597.

20 IMT, t. 1, nr 121.

21 Tamże, nr 122. Również Katarzyna Mazowiecka, córka Siemowita IV, została odsądzona od posiadania ziemi wiskiej, co nastąpiło także na mocy wyroku zwyczajnego sądu królewskiego, jaki zapadł 22 X 1468 r. Katarzyna od 27 II do 7/14 IV 1462 r. rządziła Mazowszem Zachodnim jako jej książę. IMT, t. 1, nr 124; na temat Katarzyny Mazowieckiej zob. J. Grabowski, Dynastia, op. cit., s. 342-345 i 473-474; K. Jasiński, Rodowód Piastów mazowieckich, op. cit., s. 144-148; A. Swieżawski, Katarzyna zapomniana władczyni Płocka, „Notatki Płockie”, 10/1965, s. 18-23.

22 IMT, t. 1, nr 123. 
Do 3 kwietnia I47I r. w Księstwie Mazowieckim, które wówczas obejmowało ziemie: ciechanowską, czerską, liwską, łomżyńską, nurską, różańską, warszawską, wiską, wyszogrodzką i zakroczymską, rządzili synowie Bolesława IV²3 jako władcy niedzielni. Na skutek podziału ziemia wiska znalazła się pod panowaniem księcia Kazimierza III ${ }^{24}$, który abdykował w I475 r., by objąć tron biskupi w Płocku ${ }^{25}$. Następnie ziemia wiska przeszła pod panowanie Janusza II ${ }^{26}$, który dzierżył ją aż do śmierci w I495 r. Wówczas Jan I Olbracht upomniał się o całe księstwo płockie, w tym ziemię wiską, i ostatecznie inkorporował je do Korony latem tego samego roku. Ad marginem należy dodać, że opór Mazowszan, w pełni uznających prawa spadkowe księcia Konrada III Rudego, był tak silny, że złamanie go wymagało wyprawy zbrojnej pospolitego ruszenia ${ }^{27}$.

Tym samym ziemia wiska została utracona przez władców Mazowsza. Jednakże nie był to koniec zmiennych kolei losów wzmiankowanego terytorium, albowiem już 8 marca I499 r. król polski zastawił Wiznę za sumę 3 tys. czerwonych złotych staroście gostynińskiemu Jakubowi Glince ${ }^{28}$. Problemy finansowe królów polski ${ }^{29}$ postanowiła wykorzystać księżna Anna $^{30}$, opiekunka małoletnich synów Konrada III Rudego, a zarazem regentka Księstwa Mazowieckiego, i zaczęła czynić starania, by wykupić ziemię wiską z rąk prywatnych. Do realizacji swoich ambitnych planów potrzebowała nie tylko pieniędzy, ale nade wszystko królewskiej zgody.

23 Bolesław IV Warszawski (1418/20-1454), wnuk Janusza I, od r. 1429 książę ciechanowski, czerski, liwski, łomżyński, nurski, różański, warszawski, wyszogrodzki i zakroczymski (od 1436 r. rządy samodzielne, wcześniej regencja matki Anny Fiodorówny), w latach 1440-44 władał Podlasiem. O. Balzer, Genealogia, op. cit., s. 521-522; J. Grabowski, Bolesław IV ksiaże mazowiecki (1418/20-1454), pretendent do korony polskiej, „Studia Mazowieckie", 24-25/2016, nr 2, s. 11-32; tenże, Dynastia, op. cit., s. 356 i 477-478; K. Jasiński, Rodowód Piastów mazowieckich, op. cit., s. 157-160; zob. K. Maleczyński, Bolesław IV, w: PSB, t. 2, Kraków 1936, s. 280-281.

24 Kazimierz III Płocki (1448/9-1480), syn Bolesława IV, brat Konrada III, Janusza II oraz Bolesława V. W latach 1454-71 rządził z braćmi na Wschodnim Mazowszu, zaś od 1462 r. dodatkowo w ziemi płockiej, płońskiej, wiskiej i zawkrzeńskiej, przy czym do r. 1462 w imieniu książąt regencję sprawowali ich matka Barbara Olelkówna i biskup płocki Paweł Giżycki. Od 1471 r., w wyniku podziału, książę w Płocku, Wiźnie, Wyszogrodzie, Płońsku i Zawkrzu. W 1474 r. zrezygnował z Wyszogrodu, w 1475 r. abdykował, biskup płocki od 1475 r. O. Balzer, Genealogia, op. cit., s. 530-531; J. Grabowski, Dynastia, op. cit., s. 370-373 i 487-488; K. Jasiński, Rodowód Piastów mazowieckich, op. cit., s. 174-178; zob. B. Sobol, Kazimierz III (ok. 1449-1480), w: PSB, t. 12, Wrocław-Warszawa-Kraków 1966-1967, s. 284-286.

25 IMT, t. 1, nr 126.

26 Janusz II (1452/54-1495), syn Bolesława IV, brat Konrada III, Bolesława V oraz Kazimierza III. W latach 1454-71 rządził z braćmi na Wschodnim Mazowszu, zaś od 1462 r. dodatkowo w ziemi płockiej, płońskiej, wiskiej i zawkrzeńskiej, przy czym do r. 1462 w imieniu książąt regencję sprawowali ich matka Barbara Olelkówna i biskup płocki Paweł Giżycki. Od 1471 r., w wyniku podziału, książę w Ciechanowie i Łomży, od 1475 r. w Płocku, Płońsku, Wiźnie i Zawkrzu, od 1484 r. w Błoniu i Kamieńcu, od 1489 r. w Wyszogrodzie. O. Balzer, Genealogia, op. cit., s. 534-535; J. Grabowski, Dynastia, op. cit., s. 379-384 i 493; K. Jasiński, Rodowód Piastów mazowieckich, op. cit., s. 187-188; zob. B. Sobol, Janusz II (1455-1495), w: PSB, t. 10, Wrocław-Warszawa-Kraków 1962-1964, s. $582-583$.

27 P. Trafiłowski, Koncepcje właczenia Mazowsza do Korony w późnym średniowieczu i czasach nowożytnych, „Miscellanea Historico-Archivistica”, 15-16/2008-2009, s. 32.

28 IMT, t. 2, nr 161.

29 Aleksander Jagiellończyk zastawił 17 VII 1502 r. u Jakuba Glinki, wówczas już starosty wiskiego, również Mławę za sumę 1 tys. czerwonych złotych. IMT, t. 2, nr 166.

30 Anna Radziwiłłówna (1476-1522), córka wojewody wileńskiego Mikołaja Radziwiłłowicza, od 1496 r. księżna mazowiecka i żona Konrada III Rudego, regentka Mazowsza w latach 1503-18. O. Balzer, Genealogia, op. cit., s. 528-529; J. Grabowski, Dynastia, op. cit., s. 382-384; K. Jasiński, Rodowód Piastów mazowieckich, op. cit., s. 172--174; zob. O. Halecki, Anna z Radziwittów (1476-1522), w: PSB, t. 1, Kraków 1935, s. 125-126. 
Już I9 marca I507 r., na sejmie walnym w Krakowie, Zygmunt I upoważnił Annę do wykupienia z rąk starosty wiskiego Jakuba Glinki całej ziemi wiskiej, ze wszystkimi miastami i wsiami, z zastrzeżeniem możliwości jej wykupu przez królów polskich ${ }^{31}$. Jednakże kwestia, czy ziemia wiska zostanie oddana książętom mazowieckim w wieczystą darowiznę jako lenno, nadal pozostawała otwarta, co wynikało z zapisu, że prośba dotycząca wieczystej darowizny z tych dóbr została odłożona, dla bardziej dojrzałego namysłu, na przyszłe obrady sejmu walnego ${ }^{32}$. I rzeczywiście, na sejmie w Piotrkowie Trybunalskim 2 lutego I5II r. Zygmunt I Stary wydał przywilej, na mocy którego oddał ziemię wiską, na wzór innych ziem księstwa mazowieckiego, w posiadanie księżnej Annie i jej synom, Stanisławowi33 oraz Januszowi ${ }^{34}$, a także ich prawnym następcom, przy czym zobowiązał ich do wykupienia jej z rąk spadkobierców Jakuba Glinki³5. Jednakże, aby szczodrość królewska nie została uznana za szkodliwą, król polski zastrzegł warunek, że książęta mazowieccy i ich prawowici spadkobiercy, a także ich poddani z ziemi wiskiej, mają używać tylko i wyłącznie soli z żup królewskich oraz zakazał sprowadzania na te tereny soli z innych źródeł ${ }^{36}$.

Natomiast zamek i miasto Wizna, wraz z należącymi do niego wsiami, od I509 r. znajdowały się w zastawie u Mikołaja Kościeleckiego ${ }^{37}$, starosty dobrzyńskiego, który w latach I509-II był starostą wiskim. Dlatego była konieczna odrębna sankcja królewska na wykupienie także i tych dóbr i taką zgodę król Zygmunt I wydał II lutego I5II r. na tym samym sejmie ${ }^{38}$.

Wykupienie Wizny i ziemi wiskiej nastąpiło dopiero po uchwaleniu przez sejm mazowiecki podatku nadzwyczajnego, co nastąpiło 28 kwietnia I5II r ${ }^{39}$. Na Mazowszu funkcjonowały cztery rodzaje podatków nadzwyczajnych, uiszczanych w pewnych określonych przez prawo okolicznościach, a mianowicie: małżeństwa dzieci książęcych, wykupu z niewoli monarchy i jego synów, wykupu zastawionej ziemi oraz kupna nowej, przy czym od końca XV w. obowiązywała już zasada, że na nałożenie podatków okolicznościowych obligatoryjnie

\footnotetext{
31 IMT, t. 2, nr 187.

32 ,peticionem autem ipsorum de perpetua predictorum bonorum donatione ad maturiorem deliberacionem vsque ad futurum generalem conuentum retulimus et distulimus” IMT, t. 2, nr 187, s. 125.

33 Stanisław Mazowiecki (1501-1524), syn Konrada III Rudego, brat Janusza III. W latach 1503-17 pod opieką matki Anny, regentki Mazowsza, w latach 1518-24 współrządził z bratem w Czersku, Liwie, Nurze, Warszawie oraz Zakroczmiu. O. Balzer, Genealogia, op. cit., s. 539-541; J. Grabowski, Dynastia, op. cit., s. 385-386 i 506-507; K. Jasiński, Rodowód Piastów mazowieckich, op. cit., s. 200-203; zob. K. Pacuski, Stanisław (1501-1524), w: PSB, t. 42, Warszawa-Kraków 2003-2004, s. 1-3.

34 Janusz III (1502-1526), syn Konrada III Rudego, brat Stanisława. W latach 1503-17 pod opieką matki Anny, regentki Mazowsza, w latach 1518-24 współrządził z bratem w Czersku, Liwie, Nurze, Warszawie oraz Zakroczmiu. Po śmierci brata (8 VIII 1524) rządził samodzielnie. Ostatni przedstawiciel Piastów z linii mazowieckiej. O. Balzer, Genealogia, op. cit., s. 541-543; J. Grabowski, Dynastia, op. cit., s. 386-387 i 507-508; K. Jasiński, Rodowód Piastów mazowieckich, op. cit., s. 203-205; zob. B. Sobol, Janusz III (1502-1526), w: PSB, t. 10, Wrocław-Warszawa-Kraków 1962-1964, s. 583.

35 IMT, t. 2, nr 194.

36 ,Sed ne eadem donationis noster liberalitas nobis successoribusque nostris sit damnosa, ita disponendum et ordinandum putavimus, quod tam praefata praeclara dux Anna, quam etiam praefati filii, ducibus Masoviae, praefatam terram Visnensem donatam tenendo et possidendo, non alio salis quam nostro regio ex zuppis nostris, peregrini salis inductionem prohibentes ibidem cum omnibus incolis utantur, iuxta consuetudinem aliarum terrarum, per praefata praeclaram ducem Annam, ut praemissum est, et duces praedictos ac eorum legitinum successores" IMT, t. 2, nr 194, s. 134.

37 Po śmierci Jakuba Glinki został on drugim mężem Anny z Łaskich i tą drogą wszedł w posiadanie starostwa wiskiego. P. Trafiłowski, Koncepcje, op. cit., s. 32.

38 IMT, t. 2, nr 195.

39 Tamże, nr 198.
} 
jest wymagana zgoda sejmu ${ }^{40}$. Podatek na wykup ziemi wiskiej objął całe Księstwo Mazowieckie i miał zostać uiszczony w dwóch ratach, tj. 6 maja I5II r. (najbliższe święto św. Jakuba) oraz 24 czerwca I5I2 r. (w następnym roku na święto św. Jana Chrzciciela), zaś otaksowanie wyniosło od osiadłych po I2 groszy z łanu, a od pozostałych po sześć groszy z łanu ${ }^{41}$. Poddani książąt mazowieckich musieli wywiązać się z uchwalonego zobowiązania podatkowego należycie, albowiem sąd ziemski powiatu wąsoskiego już 26 czerwca I5I r., czyli po uiszczeniu pierwszej raty podatku, stwierdził formalne przejęcie władzy nad ziemią wiską przez księżnę Annę jako opiekunkę małoletnich synów².

Natomiast 25 lutego I5I2 r. prymas Łaski oraz kasztelan sochaczewski Andrzej Radziejowski jako opiekunowie małoletnich córek zmarłego Jakuba Glinki, Anny i Katarzyny, sprzedali księżnej mazowieckiej oraz jej synom Wiznę za 6 tys. florenów³. Dyplomem, datowanym na ten sam dzień, Zygmunt I Stary stwierdził, że wszystkie osoby uprawnione zeznały, iż otrzymały od księżnej Anny i jej synów sumę wykupną z zastawu ziemi wiskiej, więc uznał roszczenia tych osób za zaspokojone i wygasłe ${ }^{44}$.

\section{Regale bartne}

Do jednych z prerogatyw gospodarczych monarchy należały regalia stanowiące jego monopole gospodarcze (np. górnicze, łowieckie, mennicze, młynne, solne, targowe, ziemi). Na Mazowszu funkcjonowało również regale bartne, czyli prawo księcia do utrzymywania w dobrach prywatnych barci pszczelnych, z których czerpał dochody ${ }^{45}$. Panujący, nadając własność ziemi, wyłączał z niej uprawnienia bartnicze, więc właściciel musiał wstrzymać się od tworzenia swoich barci w nadanych dobrach i jednocześnie musiał zezwolić na urządzanie barci przez osoby upoważnione do tego przez księcia ${ }^{46}$. Książę, jeśli taka była jego wola, mógł za opłatą oddać prawo pobierania pożytków z barci, wydzierżawiać je w zamian za ściśle określony czynsz, jaki miał składać dzierżawca, oraz darować regale czasowo, dożywotnio, a nawet i wiecznie na rzecz określonych osób ${ }^{47}$.

Regale bartne było wykonywane przez bartników książęcych, którym panujący nadawał własność użytkową barci, tym samym ograniczając prawa właściciela gruntu w zakresie swobodnego korzystania z własności ziemi. Bartnikami książęcymi byli najczęściej chłopi, ale zdarzało się, że ich szeregi zasilali mieszczanie, a nawet szlachta ${ }^{48}$. Bartnicy posiadali własną organizację, na czele której stał starosta bartny (capitaneus mellicidarum), zwany

\footnotetext{
40 P. E. Herod, Rozwój prawa mazowieckiego na tle przeobrażeń polityczno-ustrojowych Mazowsza do XVI wieku, Kraków 2016, s. 119-120.

41 „,contribucionem per totum ducatum Mazouiei habendo respectum ad iura et debita sua respectu dominorum ducum dominorum suorum, quantum ad exempcionem terrarum videlicet pro festo sancti Jacobi proximo de manso per sex grossos, de terrigenis per duodecim et sequenti anno pro festo sancti Joannis Babtiste similiter de manso per sex grossos, et de terrigensis per duodecim grossos super exepcionem terre predicte Visnensis" IMT, t. 2, nr 198, s. 138.

42 IMT, t. 2, nr 199.

43 P. Trafiłowski, Koncepcje, op. cit., s. 32.

44 IMT, t. 2, nr 202.

45 J. Rafacz, Regale bartne na Mazowszu w późnym średniowieczu, Lwów 1938, s. 4.

46 Tamże, s. 7.

47 Tamże, s. 12-13.

48 J. Senkowski, Skarbowość Mazowsza od końca XIV wieku do 1526 roku, Warszawa 1965, s. 85.
} 
również starostą obelnym, który był odpowiedzialny za poinformowanie bartników o rugu na polecenie pisarza ziemskiego, względnie starosty, za pośrednictwem podstarościego bartnego ${ }^{49}$. Jednocześnie do obowiązków podstarościego bartnego należało: pozywanie oskarżonych do sądu bartnego, ogłaszanie roków rugowych, wywoływanie posiedzeń sądowych, wzywanie stron do sądu oraz udział w czynnościach egzekucyjnych ${ }^{50}$. W skład organizacji bartnej wchodził także pisarz bartny, zaś jego głównymi obowiązkami było prowadzenie ksiąg bartnych oraz wciąganie do nich odpowiednich wpisów i wydawanie z nich wypisów, za co pobierał od stron wynagrodzenie ${ }^{51}$. Jurysdykcję nad bartnikami sprawował pisarz ziemski. Zgodnie z dekretem o bartnikach, wydanym przez radę książęcą I października I499 r. w Łomży, sądy nad wszystkimi bartnikami miał sprawować pisarz ziemski terytorialnie właściwy, czyli działający w obrębie danego powiatu ${ }^{52}$.

Najważniejszym uprawnieniem wynikającym z regale bartnego było prawo pobierania danin miodowych od bartników, którzy w imieniu władcy stosowali regale bartne w dobrach prywatnych. Podstawowym świadczeniem był miód odprowadzany do skarbca książęcego corocznie w wysokości jednej rączki. Wzmiankowana miara nie była jednolita w skali całego Mazowsza, ponieważ jedna rączka miodu mogła mieć od pięciu do 15 garnców, czyli od 20 do 60 litrów, a tzw. rączka warszawska liczyła od sześciu do dziewięciu garnców, tj. od 24 do 36 litrów53. Ponadto są poświadczone rączki mniejsze (stosowane w ziemiach wiskiej i sochaczewskiej) oraz dwukrotnie większe (obowiązywały w ziemiach warszawskiej i łomżyńskiej). Co do zasady nie zamieniano daniny miodowej na świadczenie pieniężne i zdarzało się to wyjątkowo. Poza daniną w miodzie, bartnicy książęcy byli zobowiązani do składania z każdego boru jednej skóry kuniej rocznie, przy czym nie była to zasada powszechna i jednolita jak danina miodowa, ponieważ nie stosowano jej w ziemi sochaczewskiej i nader wątpliwe jest jej stosowanie w ziemi warszawskiej ${ }^{54}$. Bartnicy składali daniny za pośrednictwem starostów bartnych na ręce pisarzy ziemskich i odbywało się to najczęściej w czasie rugów bartnych.

Książęcy monopol bartniczy nie był ustawowo unormowany i wynikał z prawa zwyczajowego. Jednakże kwestia odstępowania barci przez bartników została szczegółowo uregulowana statutem z 24 kwietnia I4OI r., który został promulgowany przez księcia Janusza I Starszego na rokach wielkich w Warszawie ${ }^{55}$. Przede wszystkim bartnik, który nie chciał lub nie mógł dzierżyć barci w jakichkolwiek dobrach dziedzicznych, był zobowiązany

\footnotetext{
49 J. Rafacz, Regale, op. cit., s. 49.

50 Tamże, s. 53.

51 Tamże, s. 52-53.

52 „quod omnes mellicidas notarius terrestris districtus illius iudicare debet” IMT, t. 2, nr 163, s. 88.

53 J. Senkowski, Skarbowość, op. cit., s. 86.

54 Tamże, s. 87.

55 IMT, t. 1, nr 55; por. Ius Polonicum, wyd. J. Bandkie, Warszawa 1831, s. 425-426; Prawa ksiązą mazowieckich / przet. na jęz. pol. przez Macieja z Różana r. 1450, przedr. homograficzny z kodeksu kórnickiego wyk. A. Piliński, Kórnik 1877, s. 11-14 (według paginacji przyjętej przez autorkę niniejszego artykułu, wobec niepoczynienia numeracji przez Macieja z Różana); por. J. Lelewel, Księgi ustaw polskich i mazowieckich, Wilno 1824, s. 140-142; Statut dotyczył nie tylko bartników i barci, ale także dochodzenia pieniężnych zobowiązań (art. 5). W wydaniach Bandtkiego oraz Lelewela przedmiotowy akt został podzielony na sześć ustępów, co jest konsekwencją tego, iż obaj badacze z drugiego artykułu wyodrębnili dwa przepisy, przy czym u tego drugiego jest to ewidentny błąd, ponieważ uznał czerwone podkreślenie u Macieja z Różana za początek nowego artykułu. Natomiast brak czerwonego nagłówka, którym zawsze Maciej z Różana oznaczał początek kolejnego przepisu, implikuje wniosek, iż dalsza część tekstu pod czerwonym podkreśleniem jest kontynuacją ustępu drugiego i nie stanowi odrębnego arty-
} 
do ich odstąpienia z jednoczesnym obowiązkiem uiszczenia panu tych dóbr lub staroście rocznej daniny miodowej w postaci albo miodu, albo podatku pieniężnego zwanego lyscz ${ }^{56}$.

Po dokonaniu odstąpienia, odstępujący bartnik był zobligowany do złożenia zabezpieczenia (poręczenia), że nie będzie niepokoił swojego następcy wyznaczonego do zarządzania barciami przez właściciela dóbr, na których te barcie się znajdują ${ }^{57}$. Jednocześnie odstępujący musiał stawić się przed oblicze pana lub wyznaczonej przez niego osoby i osobiście odstąpić barcie swojemu następcy w jego obecności ${ }^{5}$. Dodatkowo, odstępujący bartnik, który miał obowiązek uiścić daninę miodową panu lub innej uprawnionej osobie, winien był w dniu św. Wojciecha (23 IV) pokazać publicznie, przypadające na każdą rączkę miodu, po dwie żywe i zdrowe pszczoły z rojus9.

Gdyby jednak bartnik nie uczynił zadość powyższym obowiązkom, nałożonym na niego przez prawo, ponieważ odmówiłby tego albo uciekłby, to czekały go represje. Pan dóbr, na których znajdowały się opuszczone barcie, miał prawo do zatrzymania uciekiniera w każdym mieście czy wsi, w jakich by go odnalazł, przy czym miał obowiązek skorzystania przy ujęciu z pomocy starosty, a jeśli wzmiankowany urzędnik byłby nieobecny, to ujęcia należało dokonać razem z miejscowo właściwym woźnym ${ }^{60}$.

Omawiany statut przewidywał również surowe sankcje dla właściciela dóbr (miasta lub wsi), w których ukrył się uciekinier, a który odważyłby się bronić bartnika osobiście lub przez kogoś innego przed ujęciem go przez dotychczasowego pana. Wówczas taki pan miał zostać pozwany przed sąd książęcy i gdyby nie zdołał w toku przewodu sądowego oczyścić $\operatorname{sięe}^{61}$, to miał zostać ukarany dwoma karami pieniężnymi, a mianowicie karą pięćdziesiąt $(\mathrm{L})^{62}$,

kułu. P. E. Herod, Działalność ustawodawcza księcia mazowieckiego Janusza I Starszego 1381-1429, „Saeculum Christianum", 23/2016, s. 109.

56 „barthnyk in nostrarum terrarum districtibus nollet vel [non] posset seu se excusaret melificia sive apisteria, dicta barczy, per ipsum tenta et habita, regere et tenere in quacunque hereditate apud ipsum dominum, extunc illi domino vel capitaneo mellis circa pagacionem et annuam solucionem dictam 1 y s c $\mathrm{z}$ eadem mellificia debebit et tenebitur personaliter resignare" (art. 1: Modus resignacionis mellificiorum, IMT, t. 1, nr 55, s. 84).

57 „Item resignacione huiusmodi habita dictus resignans debebit ponere sufficientem caucionem fideiussoriam, quod de et super eo nunquam aliquas minas incuciat et decetero impedire et vexare non attentet hominem, in quem huiusmodi resignacio fuerit facta, et quem idem dominus pro regimine suorum mellificiorum taliter per resignacionem vacancium ordinaverit" (art. 2: Resignans mellificia caucionem imponat, IMT, t. 1, nr 55, s. 84).

58 ,et quod idem homini, in ipsa mellificia succedenti, quem idem dominus ad regenda eadem invenerit, personaliter constitutus, in presencia eiusdem domini vel vices suas gerentis dicta mellificia in personam eiusdem hominis resignabit” (art. 2: Resignans mellificia caucionem imponat, IMT, t. 1, nr 55, s. 84).

59 „Item quandocunque et quocienscunque resignans ipsa mellificia solverit suo domino vel cuius interest, extunc in die sancti Adalberti super quodlibet manuale deber educere et palam demonstrare binas apes vivas et valentes in suo examine vulgariter roy integras" (art. 2: Resignans mellificia caucionem imponat, IMT, t. 1, nr 55, s. 84-85).

60 ,extunc dominus, qui secundum huiusmodi statutum ubicumque et in quocunque oppido vel in villa ipsum fugientem invenerit, associato sibi starosta, si ipsum habet, si autem non habet, tunc cum nostro precone, cuius intererit, iuxta conssuetudinem antiquam eum fugientem impignorabit in ipso melle non soluto" (art. 3: Diffugium rectoris mellificiorum non resignantis, IMT, t. 1, nr 55, s. 85).

61 Pozwany (oskarżony) oczyszczał się poprzez złożenie tzw. odprzysiężenia, najczęściej razem ze świadkami, których liczba była przepisana przez prawo. Zarówno pozwany, jak i jego świadkowie musieli stawić się w sądzie, by wypowiedzieć spisaną przez sąd, zgodną z treścią pozwu, rotę oraz wykonać zwyczajowo przyjęte gesty, zaś cała czynność była bardzo sformalizowana. Najmniejsza pomyłka, a nawet zająknięcie się, było uznawane za dowód fałszu i wówczas strona przegrywała sprawę z mocy prawa. Przedmiotowy środek dowodowy opierał się na niezachwianym przekonaniu, że krzywoprzysięstwo zostanie ukarane przez Boga albo w doczesnym, albo przyszłym życiu. P. E. Herod, Rozwój, op. cit., s. 215-216.

62 Publiczna kara pieniężna, która była uiszczana w wysokości 50 groszy. Art. 29: De valore poenarum iudicialium, Zwód II prawa mazowieckiego, IMT, t. 3, s. 151. 
uiszczaną na rzecz księcia i jego urzędników, oraz karą piętnaście (piętnadziesta) ${ }^{63}$, którą musiał wypłacić panu, z którego dóbr bartnik zbiegł, nie rozliczając się uprzednio ${ }^{64}$.

Co ciekawe, akt z 24 kwietnia I40I r. przewidywał obostrzenie kary w przypadku recydywy oraz nadzwyczajne obostrzenie przy multirecydywie (recydywa wielokrotna). Jeśli osoba, która została uprzednio już ukarana powyższymi karami, w zatwardziałym duchu, znowu odważyłaby się bronić zbiegłego bartnika osobiście albo poprzez inne osoby, to należało pozwać ją przed sąd książęcy i, gdyby nie zdołała się oczyścić z zarzutu, ukarać ją podwójną karą pięćdziesiąt (łącznie Ioo groszy), płaconą na rzecz księcia i jego urzędników, oraz podwójną karą piętnaście (łącznie 60 groszy), uiszczaną pokrzywdzonemu panu ${ }^{65}$. Natomiast gdyby skazany recydywista znowu dopuścił się tożsamego przestępstwa, to miał zostać ukarany potrójną karą pięćdziesiąt (łącznie I50 groszy) oraz potrójną karą piętnaście (łącznie 90 groszy) $)^{66}$.

Przedmiotowy statut przewidywał takie same kary dla osób wywodzących się z ludu prostego, czyli kmieci i mieszczan, biorących w obronę zbiegłego bartnika, jeśli oczywiście nie zdołały oczyścić się z zarzutu popełnienia wzmiankowanego przestępstwa w sądzie $\mathrm{w}$ toku przewodu sądowego ${ }^{67}$. Jednakże należy zauważyć, że ustalenie w takim samym wymiarze kar pieniężnych nakładanych przez sąd na lud prosty i szlachtę stanowi ewenement w ustawodawstwie mazowieckim, które miarkowało wysokość kar pieniężnych, mając na uwadze status społeczny skazanego. Na przestępców wywodzących się ze stanu uprzywilejowanego nakładano o wiele wyższe kary pieniężne niż na przedstawicieli mieszczan czy kmieci, co było zasadne, biorąc pod uwagę ich możliwości finansowe oraz okoliczność, iż szlachta cieszyła się o wiele większymi uprawnieniami niż reszta poddanych, więc i więcej należało od niej wymagać.

Ta jaskrawa odmienność, w przypadku przestępstwa stypizowanego $\mathrm{w}$ analizowanym statucie, prowadzi do wniosku, iż książęta mazowieccy przykładali szczególną wagę do wywiązywania się przez bartników z nałożonych na nich przez prawo obowiązków. Również dlatego próbowali za pomocą surowych represji ukrócić proceder wspomagania tych nieuczciwych, nie różnicując przy tym statusu społecznego swoich poddanych, którzy

63 Publiczna kara pieniężna stanowiąca 30 groszy. Art. 29: De valore poenarum iudicialium, Zwód II prawa mazowieckiego, IMT, t. 3, s. 151.

64 „Si autem huiusmodi dominus ville vel oppidi ausu temerario, huiusmodi nostrum statutum non advertens, ipsum fugientem presumserit defendere per se vel per alium, ut premittiur, extunc ad instanciam illius, cui talis violencia facta fuerit, idem violater citabitur ad nostrum vel nostrum successorum iudicium, et si tunc citatus de eodem excessu violencie contra ipsum proposite iudicialiter se iustum non fecerit, in pena L nobis vel nostris successoribus et dominis honoratis, quibus interest, prolabetur, et suo adversario in penam, que dicitur pyącznadzeszcze" (art. 3: Diffugium rectoris mellificiorum non resignantis, IMT, t. 1, nr 55, s. 85).

${ }_{65}$, ,Si autem indurato animo idem violator iteratis vicibus eundem hominem, sic ut prefetur, profugum, per se vel per alium defendere presumserit, extunc similiter ad instanciam eiusdem citabitur, et si coram iudicio constitutus se iustum pro eodem excessu, de quo tunc accusatus fuerit, non fecerit, extunc in duplici pena LL pro nobis et dictis honoratis, et idem parti adverse in duplici pena pyacząna[dzesz]cza censemus ipsum condemnandum" (art. 3: Diffugium rectoris mellificiorum non resignantis, IMT, t. 1 , $\mathrm{nr} 55, \mathrm{~s} .85$ ).

66 „Et si punitus dictis penis et non correctus eandem violenciam in defendendo admiserit seu perpetraverit, tunc citatus, ut supra similiter dictum et, si se iustum non fecerit, in penas tres predictas condemnandus prolabetur per iudicium" (art. 3: Diffugium rectoris mellificiorum non resignantis, IMT, t. 1, nr 55, s. 85).

${ }^{67}$ „Item si kmethones ville alicuius vel incole oppidi sepius repetitam violenciam in defendendo dictum profugum perpetraverint preter mandatum et voluntatem ipsorum domini, prescriptis penis secundum morem suprascriptum omnes et singuli, si se iusti de eadem violencia, per se quilibet eorum singularuter non fecerint, puniantur" (art. 4: De repulsa insecutorum per kmethones, IMT, t. 1, nr 55, s. 85-86). 
zechcieli udzielić takiej bezprawnej pomocy. Jednocześnie należy zauważyć, że wspomaganie zbiegłych bartników musiało być na porządku dziennym w Księstwie Mazowieckim, skoro książę Janusz I Starszy zdecydował się na tak surową penalizację. Nadto należy wziąć pod rozwagę zjawisko wspomagania zbiegłych bartników przez poddanych Piastów Mazowieckich, które musiało występować nader często, co niejako potwierdza treść samego statutu, i może determinować wniosek, iż regale bartne nie cieszyło się zbytnią popularnością na Mazowszu.

\section{Spór o regale bartne między szlachtą ziemi wiskiej a bartnikami książęcymi (1502-11)}

Konflikt w przedmiocie regale bartnego rozgorzał w ziemi wiskiej z początkiem XVI w., zaś jego zarzewiem było zrównanie praw szlachty tej ziemi z prawami szlachty koronnej, kiedy rzeczone terytorium znajdowało się pod panowaniem królów polskich. Dyplomem z I4 stycznia I502 r. Aleksander Jagiellończyk zrównał ziemie płocką i wiską w prawach $z$ Koroną ${ }^{68}$, gdzie regale bartne już nie funkcjonowało i było powszechnie uznawane za relikt minionych czasów. Następnie w ziemi wiskiej musiał wybuchnąć spór w sprawie uprawnień bartniczych między starostą wiskim a szlachtą tej ziemi, albowiem został on rozstrzygnięty 29 kwietnia 1502 r., co znalazło odzwierciedlenie w treści stosownego dyplomu ${ }^{69}$. Z zachowanego dokumentu wynika, iż starosta wiski Jakub Glinka, za pośrednictwem posłów ziemi wiskiej, przedłożył na zjeździe prowincjonalnym, który został zwołany do Koła, list z prośbą o rozstrzygnięcie sporu w przedmiocie pobierania miodu i naprawy zamku, jaki istniał między nim a całą szlachtą ziemi wiskiej. Wówczas uznano, że skoro szlachta ziemi wiskiej została inkorporowana do Korony, to rzeczą właściwą jest, by została zwolniona z obowiązku naprawy zamków, zaś barcie w jej dobrach dziedzicznych nie powinny być obciążane żadnymi powinnościami, czyli mają cieszyć się wolnością, tak jak ma to miejsce w całym Królestwie Polskim ${ }^{70}$.

Aleksander Jagiellończyk potwierdził prawa szlachty ziemi wiskiej w przywileju z 4 marca I504 r., na mocy którego nadał ziemi wiskiej prawo polskie ${ }^{71}$. Król polski w powyższym dokumencie wskazał, że chce ziemię wiską upodobnić do innych ziem swojego królestwa, by ją skonsolidować i zintegrować, ponieważ w dobie panowania książąt mazowieckich jej mieszkańcy byli obciążeni wyższymi podatkami i postępowali według innych zwyczajów, sprzecznych z powszechnym prawem polskim ${ }^{72}$. Dlatego też postanowił, że niniejsza ziemia będzie się cieszyć takimi samymi wolnościami, przywilejami, prerogatywami,

\footnotetext{
68 ,approbauimus et decreuimus ipsas illas terras nostras Mazouie Plocen[sem], Viznen[sem], ac illarum inhabitatores, castrorum, ciuitatum, castellorum, opidorum, villarum incolas et eorum quemlibet, tam coniunctim quam diuisim, in et ad consuetudines, iura et priuilegia et instar aliarum terrarum regni nostri” IMT, t. 2, nr 164, s. 89.

69 IMT, t. 2, nr 165.

70 ,praesertim ex quo ipsi nobiles Viznenses Regno et praesertim Maiori Poloniae sunt incorporati. Ita visum est nobis, id fore consentaneum, ut a reformacione castri sint liberi ut mellificia libera habeant in eorum haereditatibus, prout hic in Regno Poloniae eciam per generositatem tuam nobiles terrae Viznensis immunes conserventur, plurimum affectamus" IMT, t. 2, nr 165, s. 90.

71 IMT, t. 2, nr 168.

72 „quia licet tempore olim ducem Mazovie predecessorum nostrorum maiori solucione exactionem fumalium incole illius grauarentur, allisque consuetudinibus, iuri communi regni nostri contrariis” IMT, t. 2, nr 168, s. 95.
} 
zwyczajami i prawami, jakimi od dawna cieszą się inne ziemie Królestwa Polski, zwłaszcza Wielkopolska ${ }^{73}$.

Nadanie ziemi wiskiej prawa polskiego umożliwiło szlachcie tej ziemi podjęcie odpowiednich kroków prawnych, by porozumieć się z bartnikami w kwestii likwidacji ich uprawnień bartniczych, które dla stanu uprzywilejowanego były uciążliwe. Na sejmiku ziemskim w Przytułach szlachta ziemi wiskiej zawarła 2 czerwca I506 r. ugodę z wywodzącymi się z tej ziemi bartnikami ${ }^{74}$. Porozumienie obejmowało z jednej strony całą szlachtę ziemi wiskiej, zaś z drugiej posiadaczy barci, bez względu na ich przynależność stanową, i dotyczyło przywilejów oraz uprawnień bartniczych. Na mocy rzeczonej ugody, w ciągu dwóch tygodni od jej spisania, pod rygorem obciążenia stron karą 50, każdy szlachcic winien był dokonać wykupu barci od bartnika urzędującego w jego dobrach, uiszczając mu za każdy ul cztery grosze, a za drzewo, na którym nie było barci, po pół grosza, zaś bartnicy mieli po otrzymaniu ustalonych kwot oddać użytkowane drzewa ich właścicielom ${ }^{75}$. Jednakże, jeśli jakiś szlachcic nie uiściłby wykupnego w ciągu dwóch tygodni, to bartnik mógł zatrzymać użytkowane przez siebie drzewa ${ }^{76}$.

Zawarcie ugody nie zażegnało sporu i była ona zatwierdzana aż trzykrotnie, a mianowicie najpierw przez nadworny sąd królewski, a następnie dwukrotnie przez króla polskiego, co świadczy o skali problemu i nieprzejednaniu stron konfliktu, które aktywnie broniły swoich racji. Nadworny sąd królewski zatwierdził ugodę I6 czerwca 1506 r.77, czyli zgodził się m.in. na wykupienie barci przez właścicieli dziedzicznych dóbr za kwoty i w terminie ustalonych w porozumieniu. Musiało to być jednak niewystarczające, przynajmniej dla bartników, albowiem ostatecznie sprawa trafiła przed majestat królewski. Sporna ugoda doczekała się królewskiej sankcji 5 stycznia I507 r. w Mielniku7 ${ }^{78}$ Z ogłoszonego wówczas dokumentu wynika, że bartnicy, mimo zawarcia 2 czerwca 1506 r. ugody ze szlachtą wiską i zatwierdzenia jej przez nadworny sąd królewski, nadal wytwarzali miód w borach należących do dóbr dziedzicznych bez zgody ich właścicieli, tłumacząc to tym, iż zostali uprzywilejowani przez książąt mazowieckich w borach znajdujących się również w szlacheckich dobrach dziedzicznych, za co ponosili opłaty na rzecz władców Mazowsza i nadal chcieliby takie opłaty ponosić na rzecz królów polskich ${ }^{79}$. Natomiast szlachetnie urodzeni podnieśli przed

\footnotetext{
73 ,reduximus, reinposuimus et presentibus reducimus et reinponimus, decernentes, quod futuris perpetuis temporibus in omnibus et per omnia hiisdem libertatibus, priuilegiis et prerogatius, consuetudinibus et iuribus gaudeat terra ipsa, quibus alie regni nostri terre, presertim maioris Polonie ex antiquo gaudere consveuerunt" IMT, t. 2, nr 168 , s. 95 .

74 IMT, t. 2, nr 181.

75 ,pro quibuslibet apibus, sive apisteriis per quattuor grossos et pro simplici robore, in quibus non sunt apes, per medium grossum, tam a quercus et a pino, et sic in aliis roboribus. Similiter et omnes debent tenere inter se praefatam unionem factam sub poena L principali et aliis poenis, prout iudicium decreverit in eis, non tenentibus praefatam unionem sive concordiam; et omnes, tam mellicidae, quam nobiles submiserunt se et praesentibus submittunt ad duas septimanas facere eis completam solucione et ipsi eciam mittere debent robora" IMT, t. 2, nr 181, s. 119.

76 ,et si aliquis terrigenarum non potuerit infra hoc tempus exemere, tunc mellicidae debent tenere ad debitam exolucionem" IMT, t. 2, nr 181, s. 119.

77 IMT, t. 2, nr 182.

78 Tamże, nr 183 i 184; por. KDKM, nr 282.

79 ,tanem ipsi mellicidae contra libertates praedictas mellificant suapte in borris haereditatum terrigenarum praedictorum illis non consentientibus; quibus mellicidae respondebat se ab olim ducibus Mazoviae in borris praedictis privilegiatos esse, de quibus mellifici olim ducibus Mazoviae tributa dare consueverunt et impraesentiarum nobis dare vellet" IMT, t. 2, nr 184, s. 122.
} 
królem okoliczność zawarcia ugody i przytoczyli jej treść. Po wysłuchaniu zwaśnionych stron Zygmunt I orzekł, że szlachta wiska powinna w swoich borach oraz gajach korzystać swobodnie ze wszystkich pożytków i jeśli ugoda została wpisana do księgi ziemskiej, to należy ją respektować poprzez wykupienie barci od bartników ${ }^{80}$. Gdyby jednak wzmiankowane porozumienie nie było wpisane do księgi ziemskiej, to król, biorąc pod uwagę włączenie ziemi wiskiej do Królestwa Polskiego, w którym cała szlachta korzystała swobodnie ze swoich lasów, orzekł, że szlachta wiska może wykupywać barcie i uiszczać za nie takie kwoty, jakie są zwyczajowo przyjęte w tejże ziemi ${ }^{81}$. Jednocześnie Zygmunt I ustalił, że szlachcicom, którzy nie wykupią barci, będzie się należeć od bartników opłata, jaką uprzednio uiszczali na rzecz książąt mazowieckich ${ }^{82}$.

Przytoczone rozstrzygnięcie nie zakończyło sporu i król został poproszony przez bartników, by ponownie udzielić im sprawiedliwości, ponieważ niektórzy z nich nie byli obecni w Mielniku, gdzie 5 stycznia I507 r. została zatwierdzona sporna ugoda, a także nie wszyscy zgodzili się na jej zawarcie ${ }^{83}$. Po przeanalizowaniu dokumentów przedłożonych przez strony i mając na uwadze argumentację zaprezentowaną już w dyplomie ogłoszonym w Mielniku, Zygmunt I 23 lutego I507 r. na sejmie walnym w Krakowie ponownie zatwierdził ugodę z 2 czerwca 1506 r., kończąc tym samym spór toczący się między szlachtą wiską a bartnikami użytkującymi barcie w jej dobrach dziedzicznych ${ }^{84}$.

\section{Spór o regale bartne między książętami mazowieckimi a szlachtą ziemi wiskiej (1512-19)}

Batalia o regale bartne w ziemi wiskiej wybuchła ponownie, kiedy rzeczona ziemia powróciła na łono Mazowsza, lecz tym razem adwersarzami miejscowej szlachty nie byli już bartnicy, ale władcy Księstwa Mazowieckiego. Zygmunt I potwierdził wykupienie ziemi wiskiej przez książąt mazowieckich dokumentem datowanym na 25 lutego I5I2 r. ${ }^{85}$. Anna Radziwiłłówna, regentka i opiekunka małoletnich synów, już 4 maja I5I3 r. skierowała mandat do sądów ziemi wiskiej z poleceniem, aby wzięły w opiekę i obronę bartników książęcych powiatów wiskiego i wąsoskiego przed trudnościami, jakie im czyni szlachta tych powiatów ${ }^{86}$. W powołanym

\footnotetext{
80 ,nos diffinitionem illam approbando decernim quia terrigenae praedicti borris et nemoribus ipsorum propriis omnibusque eorum comuditatibus uti debeant libere. Et si haec diffinitio continetur in libro terrestri, debeant in terrigenae secundum eandem diffinitionem mellificia suarum borrarum a mellicidis in redimere" IMT, t. 2, nr 184, S. 122 .

81 „si vero diffinitio illa non est inscripta, extunc nos, habentes respectum ad corporationem terrae illius in corpus regni nostri, ubi terrigenae borris quilibet suis libere utitur, volumus et decernimus, quod ipsi terrigenae sic solvant atque redimant mellificia praedicta, ut est in terra Viznensi consuetudo mellificia solvendi” IMT, t. 2, nr 184, s. 122.

82 „Qui vero terrigenae mellificia non redimerent, illis ipsi mellicidae tributa a mellificiis daturi sic ut ducibus, nobis tandem dare consueverunt" IMT, t. 2, nr 184, s. 122.

83 „tamen quibus nonnulli mellificatorum praedictorum, ut dicebant, concordiae illi non consenserunde aliqui etiam decreto in Myelnik non aderant, iccirco cum denuo huc nobis exponerent tanquam gravatos concordia et diffinitione praedictis peterentque iustitiam per nobis iterum inter eos ministrari” IMT, t. 2, nr 184, s. 120.

${ }^{84}$ „Nos itaque finem controversiae eiusmodi imponere volentes ac petitionibus eorundem tam consiliariorum nostrorum quam partium suprascriptarum annuentes litteras preinsertas concordiae ac decreti in omnibus punctis, clausulis et articulis approbavimus confirmavimus et contratificavimus approbamusque, confirmamus et contratificamus decernentes eas robur debitae ac perpetuae firmitatis obtinere” IMT, t. 2, nr 184, s. 122.

85 IMT, t. 2, nr 202.

86 Tamże, nr 203.
} 
dyplomie księżna wskazała, że bartnicy z powiatów wiskiego i wąsoskiego uskarżali się, że miejscowa szlachta, wbrew dawnym zwyczajom i prawom ustanowionym przez władców Mazowsza, nie pozwala im wytwarzać miodu w swoich dobrach ${ }^{87}$. Dlatego Anna zaleciła swoim urzędnikom, by zakazali szlachcie przeszkadzania bartnikom w wykonywaniu ich powinności i zezwolili im na swobodne wytwarzanie miodu w swoich lasach ${ }^{88}$. Jednocześnie księżna obiecała, że sprawa zostanie rozpoznana na najbliższym sejmie walnym, ponieważ niektórzy zaangażowani w spór chcą bronić swych praw, co jest zgodne także z jej wolą ${ }^{89}$.

Anna nie wprowadziła w życie swoich zapewnień, albowiem dopiero na sejmie, który obradował I9 stycznia I5I8 r., została poruszona kwestia krzywd wyrządzanych przez urzędników książęcych szlachcie wiskiej, lecz i tym razem księżna oraz rada książęca zawiesili rozpatrzenie przedłożonych $\mathrm{w}$ tym przedmiocie skarg9 ${ }^{90}$. Tymczasem od 4 maja I5I3 r. do I9 stycznia I5I8 r. w źródłach poświadczonych jest pięć sejmów walnych, które obradowały w Warszawie: 9 stycznia I5I4 r., 7 lutego I5I5 r., kolejny jeszcze w I5I5 r., 26 marca I5I7 r. oraz 27 maja $15 \mathrm{I} 7 \mathrm{r}$.9 $^{91}$ W omawianym okresie odbył się jeszcze jeden sejm, ale był nielegalny, bo odbył się bez woli i udziału panów przyrodzonych Mazowsza, i został zwołany przez szlachtę na 26 lipca I5I6 r. do Zakroczymia9². Ten ostatni zjazd świadczy o ogromnym kryzysie polityczno-społecznym, jaki zapanował w I5I6 r. w Księstwie Mazowieckim, i trwał jeszcze przez cały rok I5I7, a został definitywnie zażegnany dopiero przez Zygmunta I, który I4 maja I5I8 r. wydał orzeczenie w przedmiocie sporów między książętami mazowieckimi, Stanisławem i Januszem, oraz księżną Anną a szlachtą mazowiecką ${ }^{93}$.

Reasumując, kwestia regale bartnego pozostawała w zawieszeniu - najpierw władcy Mazowsza nie podejmowali tego tematu, a potem prawdopodobnie było już to niemożliwe, ponieważ w obliczu szerzących się niepokojów należało w pierwszej kolejności zająć się kwestiami ustrojowymi dotyczącymi całego państwa, a dopiero potem problemami partykularnymi, w tym przypadku istniejącymi tylko w ziemi wiskiej. Taki stan rzeczy musiał w końcu spotkać się ze stanowczym sprzeciwem zaangażowanej w spór o regale bartne szlachty wiskiej, która zaczęła zdawać sobie sprawę z tego, że jedynym orędownikiem jej sprawy będzie król polski, więc po raz kolejny należy udać się przed królewski majestat ze stosowną skargą.

Nie wiadomo, kiedy dokładnie skarga została przedstawiona Zygmuntowi I, ale I4 maja I5I8 r. król potwierdził szlachcie wiskiej wszystkie dotychczasowe jej prawa i przywileje ${ }^{94}$. Monarcha oznajmił, że ludność uprzywilejowana wzmiankowanej ziemi poskarżyła się na

\footnotetext{
87 „Expositumare nobis ex parte mellicidarum nostrorum de districtu Visnensi et Wąsochensi, quomod terrigenae distructum praefatorum in nemora sua ambulare et mellificia exercere nobis eisdem non permittunt ultra consuetudinem antiquam ac iura praedecessom illustrissimorum dominorum ducum Masoviae in damnum nostrum" IMT, t. 2, nr 203, s. 148 .

88 „Committimus vobis et mandamus, quatenus praecipiant ipsis terrigenis, ne dictos mellicidas nostros in mellificiis eorum impedire quovismodo non audeant, sed ut libere eadem mellificia exercere in nemoribus suis permittant" IMT, t. 2, nr 203, s. 148- 149.

${ }^{89}$ „Et quod iuribus nonnulli in eo se defendere cupiunt, id suspensum est generalem conventionem in ducatu proxime celebrandam, quod et nos ita fieri volumus" IMT, t. 2, nr 203, s. 149.

90 B. Sobol, Sejm i sejmiki ziemskie na Mazowszu książęcym, Warszawa 1968, s. 127-128.

91 Tamże, s. 121-126.

92 Tamże, s. 123.

93 IMT, t. 2, nr 208.

94 Tamże, nr 209.
} 
książąt mazowieckich, którzy nie chcą zachować jej praw i immunitetów przyznanych przez królów polskich ${ }^{95}$. Jednocześnie Zygmunt I przypomniał, że oddał ziemię wiską monarchom mazowieckim wraz z nadanymi jej przywilejami i immunitetami, więc władcy Mazowsza powinni zachować i respektować te prawa oraz w żaden sposób ich nie naruszać ${ }^{6}$.

Następnie 25 lipca I5I8 r. król polski wydał mandat do dostojników, urzędników i całej szlachty ziemi wiskiej, w którym wezwał do przestrzegania i niełamania dawniejszych praw i przywilejów szlachty wiskiej ${ }^{97}$. Niniejszy mandat został ogłoszony, ponieważ do Zygmunta I przybył przedstawiciel szlachty wiskiej, poseł Stefan Kowalewski z Wityniów, który oznajmił mu, że książęta mazowieccy i ich urzędnicy zmuszają groźbami stan uprzywilejowany do zrzeczenia się praw i wolności, łaskawie darowanych im przez królów polskich, narzucając im przyjęcie prawa mazowieckiego $0^{98}$. Okoliczność ta prowadzi do wniosku, że przyrodzeni panowie Mazowsza nadal nie respektowali królewskiej woli, wyartykułowanej w dyplomie wystawionym prawie dwa i pół miesiąca wcześniej, bo I4 maja I5I8 r., i nie zaprzestali naruszać praw swoich szlachetnych poddanych mieszkających w ziemi wiskiej.

W podnoszonym mandacie monarcha polski przypomniał, iż już wydał dekret, na mocy którego szlachta wiska została zachowana w prawach i wolnościach przyznanych jej przez królów polskich, i dlatego oznajmił książętom mazowieckim, za pośrednictwem ich posłów, to samo, napominając przy tym, żeby nie zmuszali szlachty do zrzeczenia się przez nią swoich wolności ${ }^{99}$. Jednocześnie Zygmunt I wskazał, że jeśli jakiś szlachcic będzie miał wolę ku temu, by zrzec się tych praw i wolności, to pozostawia to tylko i wyłącznie do jego decyzji, ponieważ nie chce, by ktokolwiek był do tego zmuszany ${ }^{100}$.

Zarówno pierwszy, jak i drugi dekret nie przyniosły spodziewanego efektu, ponieważ król polski po raz trzeci musiał wypowiedzieć się w spornej materii, wobec braku jakiegokolwiek posłuchu u władców Mazowsza. Co prawda, na sejmie zwołanym do Zakroczymia na 29 czerwca 1518 r. poruszono kwestię, czy należy utrzymać w ziemi wiskiej prawa i swobody nadane jej przez Zygmunta I, czy też przywrócić w niej prawo książęce, ale nie podjęto w tym przedmiocie żadnej merytorycznej decyzji ${ }^{10}$. W konsekwencji, II marca I5I9 r., na sejmie walnym w Piotrkowie, król potwierdził po raz trzeci szlachcie wiskiej wszystkie dawniejsze prawa i przywileje, a także wezwał księżnę Annę i jej synów do ich przestrzega-

\footnotetext{
95 „quia cum nobiles terre Visnen[sis] quererentur nobis, quod illustres domini Anna mater et Stanislaus ac Ianussius duces Mazouie illis iura et immunitates, a nobis et predecessoribus nostris concessas, seruare nollent et nos meminimus et scimus eis a nobis et eisdem predecessoribus nostris" IMT, t. 2, nr 209, s. 155.

96 „nosque cum eisdem priuilegiis et immunitatibus terram ipsam Visnensem dictis dominis Mazouie dedimus et tradidimus" IMT, t. 2, nr 209, s. 155.

97 IMT, t. 2, nr 211.

98 „Significastis nobis per nuntium vestrum nobilem Stephanum Kovalewksi [de] Vithinye, quod illustres domini duces Mazoviae eorumque officiales minis ac terroribus cogerent vos ad renunctiandum iuribus et libertatibus, vobis a praedecessoribus nostris et nobis ipsis gratiose donatis et iura ipsorum ducalia, ita ut alii illorum subditi, suscipienda" IMT, t. 2, nr 211, s. 157.

99 „Nos declaravimus iam antea vobis omnibus per decretum nostrum, qoud vos in iuribus et libertatibus, per nos et praedecessores nostros vobis concessis, conservari volumus et id ipsum his diebus ipsis illustribus ducibus vestris medio oratorum eorundem, quos apud nos habuerant, denuntiavimus; hortatique sumus illos, ut neminem vestrum minis aut coactione aliqua cogerent ad abrenunctiandum libertatibus suis" IMT, t. 2, nr 211, s. 157.

100 „Si vero aliqui vestrum renunctiare vellent his ipsis iuribus et libertatibus, gratiose illis per nos et praedecessores nostros donatis, id uniuscuiusque arbitrio et voluntati relinquimus, neminem tamen ad id faciendum cogi volumus" IMT, t. 2, nr 211, s. 157.

101 B. Sobol, Sejm, op. cit., s. 132.
} 
nia $^{102}$. Zygmunt I orzekł, za zgodą i radą całego gremium senatorów, iż wszystkie przywileje i immunitety szlachty wiskiej, darowane jej przez polskich monarchów, zostały przez niego już zatwierdzone oraz ratyfikowane, lecz również przedmiotowym dokumentem zatwierdza je i ratyfikuje, postanawiając, że mają one moc wieczystą ${ }^{103}$. Jednocześnie monarcha wskazał, że chce, by księżna Anna oraz jej synowie, Stanisław i Janusz, przestrzegali praw nadanych szlachcie wiskiej przez królów polskich i zachowali je nienaruszone ${ }^{\mathrm{I} 4}$.

W obliczu przeciągającego się konfliktu i zajmowania przez Zygmunta I konsekwentnego oraz precyzyjnie uargumentowanego stanowiska, regentka Księstwa Mazowieckiego wydała 7 kwietnia I5I9 r. w Łomży przywilej ziemski, w którym zatwierdziła prawa szlachty wiskiej oraz ogłosiła szczegółowe postanowienia co do „nieuciążania” jej przez miejscowych urzędników w przedmiocie barci, płacenia podatków i wymiaru sprawiedliwości ${ }^{105}$. Księżna, idąc za decyzją i wolą świętego majestatu królewskiego, postanowiła mocą niniejszego dokumentu zachować, zgodnie z pragnieniami szlachty wiskiej, prawa i przywileje przyznane jej przez królów polskich ${ }^{106}$. Jednocześnie Anna Radziwiłłówna nakazała miejscowym urzędnikom, tj. staroście, pisarzowi ziemskiemu i ich zastępcom, by rządzili i kierowali szlachtą wiską zgodnie z treścią nadanych im praw i przywilejów oraz nie ważyli się czynić nikomu spośród niej gwałtów i przemocy ${ }^{107}$. W przedmiocie regale bartnego księżna Anna zobowiązała powyżej wskazanych urzędników do wydania bartnikom, którzy uprzednio wykonywali swoje bartnicze powinności w dobrach dziedzicznych szlachty wiskiej, zakazu korzystania z uli znajdujących się w tych posiadłościach ${ }^{108}$.

Abstrahując od tego, że szlachta wiska ostatecznie wygrała batalię z książętami mazowieckimi o regale bartne, na wszelki wypadek postanowiła zaopatrzyć się w teksty przywilejów, którymi obdarowali ich polscy monarchowie. Sejmik ziemski ziemi wiskiej już I2 kwietnia I5I9 r., czyli pięć dni po promulgowaniu przez księżnę Annę przywileju dla miejscowej szlachty, podjął uchwałę, na mocy której nałożono na szlachtę tej ziemi kontrybucję ziemską w wysokości dwóch groszy z łanu, celem wykupienia z kancelarii królewskiej dokumentów z przywilejami dla szlachty wiskiej ${ }^{109}$.

\footnotetext{
102 IMT, t. 2, nr 214.

103 „de consilio et consensu universorum consiliariorum nostrorum privilegia et immunitates omnes ipsorum Visnensium a praedecessoribus nostris regibus Poloniae illis donates et concessas confirmavimus et ratificavimus, confrimamusque et ratificamus tenore praesentium, decernentes ea robui debitae firmitatis perpetue obtinere debere" IMT, t. 2, nr 214, s. 159.

104 ,et volentes, ut ea illis opsa domina Anna mater et eius filli Stanislaus et Ianussius duces Masoviae teneant et inviolabiliter observent" IMT, t. 2, nr 214, s. 159.

105 IMT, t. 2, nr 215.

106 „quia sacrae maiestatis regiae, domini nostri clementissimi, arbitrio et voluntati diferentes ac in toto satisfieri volentes nobilitatem certam terrae nostrae Visnensis, quae in iuribus et privilegiis, per maiestatem regiam eisdem concessis conservari cupit, eandem nobilitatem conservare et fovere in eisdem decrevimus et constituimus praesentibus" IMT, t. 2, nr 215, s. 160.

107 „Quapropter vobis capitaneo et terrestri notario, nostris Visnensibus, pro nunc et in futurum existentibus et pro tempore constitutis eorumque loca terentibus ac vicesgerentibus iniungimus et stricte praecipientes mandamus, quatinus secundum exigentiam et continentiam iurium seu privilegiorum regalium nobilitatem eandem terrae Visnensis regant et foveant nullasque invasiones et violentias ipsis et ipsorum cuilibet praesemant exercere" IMT, t. 2, nr 215, s. 160.

108 „Caeterum mellicidis, qui ante sua apisteria in haereditatibus terrae eiusdem Visnensis nobilium habuerunt et sint exempti, demandent et inhibeant, ne deinceps utantur eisdem apisteriis” IMT, t. 2, nr 215, s. 160.

109 IMT, t. 2, nr 216.
} 


\section{Podsumowanie}

Spór o regale bartne toczył się w ziemi wiskiej przez siedemnaście lat (I502-I9), a zapoczątkowało go zrównanie praw szlachty rzeczonej ziemi z prawami szlachty koronnej, co nastąpiło na skutek decyzji Aleksandra Jagiellończyka, której dał wyraz w dokumencie z I4 stycznia I502 r. Najpierw miejscowa szlachta walczyła z samymi bartnikami, którzy robili wszystko, by utrzymać się w barciach nadanych im przez władców Mazowsza. Następnie ich przeciwnikami zostali książęta mazowieccy, którym udało się wykupić ziemię wiską z rąk prywatnych, na co zezwolił Zygmunt I.

Król nieodmiennie stał po stronie szlachty, argumentując swoje stanowisko faktem, że ziemia wiska została inkorporowana do Królestwa Polski i zrównana w prawach z innymi ziemiami polskimi. Jednakże status prawny ziemi wiskiej nie był już taki jednoznaczny, kiedy na powrót stała się częścią władztwa Piastów Mazowieckich. Wówczas pojawił się problem prawny, czy na wzmiankowanym terytorium należy stosować prawo polskie, czy też podlega ono znowu prawu mazowieckiemu. Wydaje się jednak, że wątpliwości w tej materii mogli mieć jedynie książęta, ponieważ król polski i szlachta ziemi wiskiej konsekwentnie obstawali przy prawie polskim, zaś bartnicy książęcy przy prawie mazowieckim.

Władcy Mazowsza najczęściej nie podejmowali ostatecznych decyzji w tym zakresie, przesuwając wszystko w czasie i unikając kategorycznych wypowiedzi, co nie musi świadczyć o targających nimi wątpliwościach, ale o wytrawnej grze politycznej, zasadniczo prowadzonej przez Annę Radziwiłłównę - ówczesną regentkę, opiekunkę małoletnich synów oraz inicjatorkę przywrócenia ziemi wiskiej na łono Księstwa Mazowieckiego.

Dla Zygmunta I spór o regale bartne w ziemi wiskiej musiał być bardzo istotny, ponieważ godził w jego królewski majestat i prestiż. Skoro jego królewski brat nadał szlachcie wiskiej prawo polskie, zaś on je potwierdził, to na tym terytorium mogło obowiązywać tylko jedno prawo, oczywiście polskie. Sytuacji nie zmieniał fakt wykupienia ziemi wiskiej z rąk prywatnych, albowiem przywileje i immunitety królewskie nadal w niej obowiązywały.

Mając powyższe na uwadze, należy zauważyć, że spór o regale bartne w latach I5I2-I9 był tak naprawdę sporem o władzę między królami polskimi a książętami mazowieckimi. Walka to była nierówna i jej rezultat był przesądzony u zarania konfliktu, ponieważ w omawianym okresie władcy Mazowsza nie reprezentowali już takiej władzy, jaką mieli w ubiegłych wiekach. Nie byli suwerenni i popadli w zależność od królów polskich, stając się ich lennikami.

Ostatni książęta mazowieccy, Stanisław i Janusz III, byli lennikami królów polskich z ziem ciechanowskiej, czerskiej łomżyńskiej, warszawskiej, wyszogrodzkiej i zakroczymskiej $^{\text {IIO }}$, a od I5II r. również z ziemi wiskiej. Książęta nie złożyli hołdu Zygmuntowi I, lecz król się na to godził, ponieważ sam odkładał termin jego złożenia ${ }^{\text {III }}$, ale nie oznaczało to, że tak już pozostanie. Mimo tego, że rodzima ludność była przywiązana do książąt mazowieckich jako do panów przyrodzonych Mazowsza, wywodzących się z jakże poważanej, także w Koronie, dynastii piastowskiej, to jako lennicy królów polskich nie mogli oni lekceważyć królewskiej woli ani sprzeniewierzać się ustanowionym przez nich prawom. Zasadniczo ta właśnie okoliczność potęgowała spór i wymagała energicznego działania Zygmunta I, który ostatecznie z tej batalii wyszedł zwycięsko.

${ }_{110}$ IMT, t. 2, nr 169, 171, 172 i 237.

111 Tamże, nr 205 i 243. 
Jednocześnie należy wskazać, iż uznawanie króla polskiego za przeciwnika regale bartnego byłoby nieporozumieniem, o czym świadczy to, że po wcieleniu całego Księstwa Mazowieckiego do Korony, Zygmunt I usilnie próbował zachować wzmiankowany monopol gospodarczy, wówczas już królewski, na reszcie terenów mazowieckich. Najpierw I4 października I533 r. król wydał mandat do starosty warszawskiego Jana Dzierzgowskiego, polecający przestrzegać ustalonych zasad jurysdykcji nad bartnikami królewskimi i stawać w obronie bartników krzywdzonych przez szlachtę, na której gruntach posiadają barcie ${ }^{\mathrm{II} 2}$. Następnie 9 października I535 r. Zygmunt I ogłosił mandat do wszystkich starostów księstwa mazowieckiego, aby wobec bartników królewskich przestrzegali ustalonych zasad jurysdykcji w sporach o ich czynsze mające wpływać do skarbu królewskiego ${ }^{\text {II3 }}$. Przytoczone działania króla polskiego prowadzą do wniosku, że w sporze o regale bartne, jaki zaistniał w obrębie ziemi wiskiej, chciał jedynie wyegzekwować swoje prawa do zwierzchności nad tym terytorium oraz nad własnymi lennikami, którzy nie chcieli respektować nadanych szlachcie wiskiej przez władców Królestwa Polskiego praw, sprzecznych z ustawodawstwem mazowieckim.

Konkludując, regale bartne nie jawiło się Zygmuntowi I jako prawo przestarzałe i niesłuszne. Król polski nie mógł go wykonywać na ziemiach koronnych, ponieważ już tam od dawna nie funkcjonowało. Po obdarzeniu ziemi wiskiej prawem polskim nie mógł przyzwolić na jego stosowanie również w tejże ziemi, albowiem godziłoby to w jego prerogatywy. Natomiast mógł zachować regale bartne na innych ziemiach mazowieckich i podjął w tym kierunku odpowiednie kroki, więc jednak chciał przedmiotowy monopol utrzymać w mocy. Jednakże szlachta mazowiecka, nie tracąc z pola uwagi casusu szlachty wiskiej, wywalczyła zniesienie regale bartnego we wszystkich ziemiach mazowieckich, co nastąpiło w roku I53 ${ }^{114}$.

\section{The dispute over beekeeping regalia in Wizna Land in 1502-1519}

\section{Abstract}

The article describes, on the basis of preserved documentary sources, the reasons for, and the course and resolution of the dispute about beekeeping regalia in the Wizna Land, which lasted in I502-I9, and ended only thanks to the intervention of the Polish king Sigismund I. First, the dispute between the nobility of Wizna and the beekeepers (I502-II) is discussed, and then the one between the aforementioned nobility and the Mazovian dukes (I5I2-I9). At the same time, the only princely statute devoted to the beekeeping monopoly, which was promulgated by prince Janusz I the Elder on 24 April I4OI in Warsaw, receives an in-depth analysis. The whole article is concluded with a presentation of research results.

Key words: Beekeeping regalia, Mazovian law, Vistula land, Sigismund I Old, Anna Radziwill

\footnotetext{
112 IMT, t. 3, nr 334.

113 Tamże, nr 342.

114 J. Rafacz, Regale, op. cit., s. 65.
} 


\section{BIBLIOGRAFIA}

\section{I. Źródła}

Iura Masoviae Terrestria: pomniki dawnego prawa mazowieckiego ziemskiego, wyd. J. Sawicki, t. I: I228-I47I, Warszawa 1972; t. 2: I47I-I526, Warszawa I973; t. 3: I526-I540, Warszawa 1974.

Ius Polonicum, wyd. J. Bandtkie, Warszawa I83I.

Kodeks dyplomatyczny Księstwa Mazowieckiego, obejmujacy bulle papieżów, przywileje królów polskich i książąt mazowieckich, tudzież nadania tak korporacyj jako i osób prywatnych, red. J. Lubomirski, Warszawa 1863.

Lelewel J., Ksiegi ustaw polskich i mazowieckich, Wilno I824.

Nowy kodeks dyplomatyczny Mazowsza, cz. 3: Dokumenty z lat I356-I38I, red. J. Sułkowska-Kuraś, S. Kuraś, Wrocław 2000.

Prawa ksiąząt mazowieckich / przel. na jęz. pol. przez Macieja z Różana r. I450, przedr. homograficzny z kodeksu kórnickiego wyk. A. Piliński, Kórnik I877.

Szacherska S. M., Zbiór dokumentów i listów miasta Płocka, t. I, Warszawa 1975.

\section{Literatura}

Atlas historyczny Polski. Mazowsze w drugiej połowie XVI wieku, cz. 2, red. W. Pałucki, Warszawa 1973.

Balzer O., Genealogia Piastów, Kraków I895.

Brodzicki C., Poczatki osadnictwa Wizny i ziemi wiskiej na tle wydarzeń historycznych w tym regionie Polski (do I529 roku), Warszawa 2000.

Brodzicki C., Ziemia wiska pod rzadami księcia Władysława I (I435-I455), „Notatki Płockie”, I64/1995, nr 4, s. IO-I5.

Dunin K., Dawne mazowieckie prawo, Warszawa I880.

Dzieje Mazowsza, t. I, red. H. Samsonowicz, Pułtusk 2006.

Grabowski J., Bolesław IV ksiązę mazowiecki (I4I8/20-I454), pretendent do korony polskiej, „Studia Mazowieckie”, 24-25/20I6, nr 2, s. II-32.

Grabowski J., Dynastia Piastów mazowieckich. Studia nad dziejami politycznymi Mazowsza, intytulacja i genealogia książąt, Kraków 2012.

Grabowski J., Kancelarie i dokumenty ksiażat mazowieckich, Warszawa 1999.

Halecki O., Anna z Radziwiłtów (I476-I522), w: Polski Stownik Biograficzny (dalej: PSB), t. I, Kraków 1935, s. I25-I26.

Herod P. E., Działalność ustawodawcza księcia mazowieckiego Janusza I Starszego I38II429, „Saeculum Christianum”, 23/20I6, s. I03-I24.

Herod P. E., Rozwój prawa mazowieckiego na tle przeobrażeń ustrojowo-politycznych Mazowsza do XVI wieku, Kraków 2016.

Jasiński K., Rodowód Piastów mazowieckich, Poznań-Wrocław 1998.

Jasiński K., Siemowit III (ok. I320-I38I), w: PSB, t. 37, Warszawa-Kraków I996-I997, s. 73-75.

Maleczyński K., Bolesław IV, w: PSB, t. 2, Kraków 1936, s. 280-28I.

Pacuski K., Stanisław (I50I-I524), w: PSB, t. 42, Warszawa-Kraków 2003-2004, s. I-3.

Pacuski K., Swieżawski A., Siemowit VI (ok. I446-I462), w: PSB, t. 37, Warszawa-Kraków I996-I997, s. 84-85.

Rafacz J., Regale bartne na Mazowszu w późnym średniowieczu, Lwów 1938. 
Senkowski J., Skarbowość Mazowsza od końca XIV wieku do 1526 roku, Warszawa 1965.

Sobol B., Janusz I Starszy (ok. I329-I429), w: PSB, t. IO, Wrocław-Warszawa-Kraków I962I964, S. 58I-582.

Sobol B., Janusz II (I455-I495), w: PSB, t. IO, Wrocław-Warszawa-Kraków I962-I964, S. 582-583.

Sobol B., Janusz III (I502-I526), w: PSB, t. IO, Wrocław-Warszawa-Kraków I962-I964, s. 583.

Sobol B., Kazimierz III (ok. I449-I480), w: PSB, t. I2, Wrocław-Warszawa-Kraków I966-1967 , s. $284-286$.

Sobol B., Konrad Rudy III (ok. I448-I503), w: PSB, t. I3, Wrocław-Warszawa-Kraków I967-I968, s. 595-597.

Sobol B., Sejm i sejmiki ziemskie na Mazowszu książęcym, Warszawa I968.

Supruniuk A., Siemowit IV (ok. I352-I426), w: PSB, t. 37, Warszawa-Kraków I996-I997, s. 76-8I.

Swieżawski A., Katarzyna zapomniana władczyni Płocka, „Notatki Płockie”, Io/ı965, s. I8-23.

Trafiłowski P., Koncepcje włączenia Mazowsza do Korony w późnym średniowieczu i czasach nowożytnych, „Miscellanea Historico-Archivistica”, I5-I6/2008-2009, s. 25-52. 